This is an Open Access article distributed under the terms of the Creative CommonsAttribution 4.0 International License which permits unrestricted non-commercial use, distribution, and reproduction in any medium, provided the original work is properly cited.

http://ijnms.net/index.php/ijnms

\title{
Risk Factors That Cause Stunting in Indonesia
}

\section{AriefAndriyanto*, Faisal Ibnu**, Rina NurHidayati*** \\ *Graduate Student of The Faculty of Nursing, University of Indonesia \\ **Doctoral Student of The Faculty of Nursing, University of Indonesia \\ ***Lecturer STIKes Bina Sehat PPNI Mojokerto}

\section{INTRODUCTION}

The Sustainable Development Goals are emphasizing an intervention to prioritize solutions to the global challenge of poor child development in low and middleincome countries (LMICs). In 2015, about $25 \%$ of children under five years of age in low were stunted (Kim \& Subramanian, 2017; Perkins et al., 2017; UNICEF, 2015).

Globally, the prevalence of stunting among children under age five has decreased. At the regional level, as compared to other regions, the very little decline in the prevalence of stunting is documented in Africa. East Africa and South-Central Asia had the highest prevalence of stunting. East Africa at $42 \%$, and South-Central Asia at $36 \%$ (Black et al., 2013; Hagos, Hailemariam, Woldehanna, \& Lindtj, 2017; Onis et al., 2013). In 2012, the WHO sets a global target to reduce the number of stunted children by $40 \%$ from the baseline 171 million in 2010 to 100 million by 2025 (Onis et al., 2013). The prevalence of stunting was $28 \%$ among lower-middle-income countries and $7.2 \%$ among high-income countries (Black et al., 2013).

This causes the death of 3 million children per year. In the year of 2011, Indonesia is ranked 5 of 81 countries with the largest number of stunted children in the world that reached 7.547.000 children. Indonesia is reported to have a larger number of stunting children than some African countries, such as Ethiopia, the Democratic Republic of the Congo, Kenya, Uganda, and Sudan. Cases stunting in Indonesia year of 2015 as much $18,9 \%$ short and $10,1 \%$ very short, while in 2016 there $19,0 \%$ short and 8,6\% very short, this occurs at the age of 0-59 months(Hardhana et al., 2017; Ohyver, Moniaga, \& Restisa, 2017).

Risk factors for stunting cases in this Indonesia were analyzed descriptively, so we get the factors maternal nutrition, infection, teenage motherhood and short birth intervals, fetal growth restriction, preterm birth, childhood nutrition and environmental factors (Danaei et al., 2016). Fetal growth restriction, preterm birth and environmental are the leading risk factors worldwide (Novotny et al., 2017).

\section{CONCLUSION}

The WHO conceptual framework for stunting (2013) identified household and family factors, complementary feeding, breastfeeding practices and infections as the most plausible causes of stunting (Stewart, Iannotti, Dewey, Michaelsen, \& Onyango, 2013). Contextual factors at community and 
societal levels such as beliefs, norms, and livelihoods influence the proximate causes of stunting. Many studies corroborated in reporting significant association with Mother's education, household wealth, maternal age, child's gender, marital status, dietary diversity, parity, pregnancy intentions, health-seeking behaviour from the mother, socioeconomic status, diseases and infections are strongly associated with stunting(Abuya, Ciera, \& Kimani-Murage, 2012; Hagos et al., 2017).

Stunting prevalence may vary across space at different scale. For this, it is important to study nutrition through several studies to provide control interventions taking into account the nutritional deficit distribution and its underlying origin factors. Thus, geographically targeted nutritional interventions may be more efficient and cost-effective if done in a similar way that has been done in developing countries. The findings of this study also indicated that interventions integrating household food insecurity in nutrition programs in the district might help to avert the burden of stunting.

\section{CONFLICT}

OF

INTEREST

\section{STATEMENT}

We declare that we have no conflict of interest.

\section{REFERENCES}

Abuya, B., Ciera, J., \& Kimani-Murage, E. (2012). Effect of mother's education on child's nutritional status in the slums of Nairobi.

Black, R., Victora, C., Walker, S., Bhutta, Z., Christian, P., \& Onis, M. de. (2013). Maternal and child undernutrition and overweight in low-income and middle-income countries, 382:427-51.

Danaei, G., Andrews, K., Sudfeld, C., Fink,
G., McCoy, D., \& Peet, E. (2016).

Risk Factors for Childhood

Stunting in 137 Developing

Countries: A Comparative Risk

Assessment Analysis at Global, Regional, and Country Levels.

Retrieved from

doi:10.1371/journal.pmed.1002164. collection 2016

Hagos, S., Hailemariam, D., Woldehanna, T., \& Lindtj, B. (2017). Spatial heterogeneity and risk factors for stunting among children under age five in Ethiopia: A Bayesian geostatistical model, 1-19. https://doi.org/10.1371/journal.pon e.0170785

Hardhat, B., Budiono, C. S., Kurniasih, N., Manullang, E. V, Susanti, M. I., Pangribowo, S., ... Sigit, B. B. (2017). Data dan Informasi Profil Kesehatan Indonesia 2016.

Kim, R., \& Subramanian, S. V. (2017). Social Science \& Medicine Relative importance of 13 correlates of child stunting in South Asia: Insights from nationally representative data from Afghanistan, 187. https://doi.org/10.1016/j.socscimed. 2017.06.017

Novotny, R., Li, F., Guerrero, R. L., Coleman, P., Tufa, A. J., Bersamin, A., ... Wilkens, L. R. (2017). Dual burden of malnutrition in US Affiliated Pacific jurisdictions in the Children ' s Healthy Living Program, 1-8. https://doi.org/10.1186/s12889017-4377-6

Over, M., Moniaga, J. V, \& Restisa, K. (2017). ScienceDirect Logistic Regression and Growth Charts to Determine Children Nutritional and Stunting Status: A Review. Procedia Computer Science, 116, 232-241.

https://doi.org/10.1016/j.procs.2017 
Onis, D., KG, D., E, B., Onyango, Blossner, \& Al., D. (2013). The World Health Organization's global target for reducing childhood stunting by 2025: rationale and proposed actions, 9 Suppl 2.

Perkins, J. M., Kim, R., Krishna, A., Mcgovern, M., Aguayo, V. M., \& Subramanian, S. V. (2017). Social Science \& Medicine Understanding the association between stunting and child development in low- and middle-income countries: Next steps for research and intervention. Social Science \& Medicine, 193, 101-109.

https://doi.org/10.1016/j.socscimed. 2017.09.039

Stewart, C., Iannotti, L., Dewey, K., Michaelsen, K., \& Onyango, A. (2013). Contextualising complementary feeding in a broader framework for stunting prevention, 9 Suppl 2.

UNICEF. (2015). Levels and Trends in Child Malnutrition: Key Findings of the 2015 Edition. United Nations Children's Fund, World Health Organization, and World Bank Group. 